\title{
Molecular changes associated with the agonist activity of hydroxy-tamoxifen and the hyper-response to estradiol in hydroxy-tamoxifen-resistant breast cancer cell lines
}

\author{
J A Vendrell, I Bieche ${ }^{1}$, C Desmetz, E Badia ${ }^{2}$, S Tozlu ${ }^{1}$, C Nguyen ${ }^{3}$, \\ $J$ C Nicolas ${ }^{2}, R$ Lidereau $^{1}$ and $P$ A Cohen
}

\author{
CNRS UMR 5160, Faculté de Pharmacie, 15 Av Charles Flahault, BP 14491, 34093 Montpellier Cedex 5, France \\ ${ }^{1}$ Laboratoire d'Oncogenetique-INSERM E0017, Centre René Huguenin, 92210 St-Cloud, France \\ ${ }^{2}$ INSERM U540, 70 Rue de Navacelles, 34090 Montpellier, France \\ ${ }^{3}$ Laboratoire TAGC, CIML, Université d'Aix-Marseille II, 13288 Marseille Cedex 9, France
}

(Requests for offprints should be addressed to PA Cohen; Email: pascale.cohen@ibph.pharma.univmontp1.fr)

\begin{abstract}
The aim of this study was to explore the pharmacological response to 4-hydroxy-tamoxifen $(\mathrm{OH}-\mathrm{Tam})$ and to estradiol $\left(\mathrm{E}_{2}\right)$ in three cell lines: MVLN, a human breast carcinoma cell line derived from MCF-7, and two MVLN-derived OH-Tam-resistant (OTR) cell lines, called CL6.8 and CL6.32. The $\mathrm{OH}-\mathrm{Tam}$ response in the OTR cells was associated with the development of both an agonist activity of the drug on cell proliferation and the resistance of the cells to $\mathrm{OH}$-Tam-induced apoptosis. The OTR cells also developed an increased sensitivity to the $E_{2}$ growth-stimulating activity. To delineate the genes that determine such responses, we combined a mini-array-based geneselection approach and an extensive real-time quantitative PCR exploration in the MVLN and OTR cell lines exposed to three pharmacological conditions: a 4-day treatment with $\mathrm{E}_{2}, \mathrm{OH}$-Tam or both $\mathrm{E}_{2}$ and $\mathrm{OH}-\mathrm{Tam}$. Compiled data revealed a hyper-response to $\mathrm{E}_{2}$ and a modification of the $\mathrm{OH}-\mathrm{Tam}$ pharmacological response (loss of antagonist action and agonist activity) at the gene-expression level. The proteins encoded by the genes selected in this study have been reported to be involved in the regulation of cell proliferation, cell transformation, DNA repair and apoptosis, or belong to the ErbB/epidermal growth factor receptor-driven pathway. Our data also provide evidence of changes in transcriptional co-regulator expression, elevated mitogen-activated protein kinase activity and increase in the phosphorylation status of estrogen receptor $\alpha$ on serine residue 118 in the OTR cell lines, suggesting the possible involvement of such mechanisms in the agonist activity of OH-Tam and/or the hyper-response of cells to $E_{2}$. Taken together, our study should enhance our knowledge of the multifactorial events associated with the development of Tam resistance in two independent cell lines issued from the same selection process and should help in the identification of potential molecular targets for diagnosis or therapy.
\end{abstract}

Endocrine-Related Cancer (2005) 12 75-92

\section{Introduction}

The estrogen receptor $\alpha(\mathrm{ER} \alpha)$ plays a crucial role in the clinical care of breast cancer patients, and measurement of the level of ER $\alpha$ expression has allowed an accurate prediction of the response to endocrine therapy. The selective estrogen receptor modulator
(SERM) tamoxifen (Tam) and its active metabolite 4-hydroxy-tamoxifen (OH-Tam) have been shown to be an effective adjuvant therapy for ER $\alpha$-positive tumors by reducing the incidence of contralateral breast cancer by $50 \%$ (EBCTC Group 1992). However, despite its widespread use in clinical practice, acquired resistance develops in almost all Tam-treated 
women after long-term medication (Johnston 1997). The molecular mechanism leading to Tam resistance is not fully understood, and multifactorial changes leading to a survival system for the cancer cells seem to be involved, rather than a gain- or loss-of-function mechanism (Brockdorff et al. 2003). Cellular disturbances have been reported as being possibly involved in the emergence of Tam resistance, such as modifications in Tam metabolism (Osborne 1993), ER mutations (Mahfoudi et al. 1995), altered ER $\alpha$ or ER $\beta$ expression (Johnston et al. 1995, Speirs et al. 1999), qualitative and/or quantitative changes in transcriptional co-repressors or co-activators (Girault et al. 2003a, Osborne et al. 2003) and phosphorylation of $\mathrm{ER} \alpha$ by mitogen-activated protein kinase (MAPK; Kato et al. 1995), phosphoinositide 3-kinase/Akt (Campbell et al. 2001) or protein kinase A (Le Goff et al. 1994, Michalides et al. 2004). There is also compelling evidence that inappropriate activation of growth factor signaling cascades (e.g. by overexpression of heregulins, transforming growth factor $\alpha(\mathrm{TGF} \alpha)$, epidermal growth factor receptor (EGFR) and HER2/erbb2 (Liu et al. 1995, Lupu et al. 1996, Nicholson et al. 2001)) could promote endocrine resistance. Supporting data show that MAPK activity is increased in breast cancer cell-line models of endocrine resistance (Coutts \& Murphy 1998) and correlates with a shorter duration of response to endocrine therapy in clinical breast cancer (Gee et al. 2001). During the progression of Tam resistance, an important step is the loss of the anti-estrogen activity of Tam and the passage to an agonist activity of Tam-ER complexes (Gottardis \& Jordan 1988, Ring $\&$ Dowsett 2004). Possible mechanisms involved in the emergence of such agonist activity of the drug are modification of the ER $\alpha$ conformation or activity by phosphorylation of key regulatory sites in the AF-1 domain (Ser-118) or the hinge region (Ser-305) (Kato et al. 1995, Michalides et al. 2004) and qualitative and/ or quantitative changes in transcriptional co-regulators (Shang \& Brown 2002).

Today, information emerging from data in vitro and in vivo provides evidence that under deprivation of estrogens or blockade of estrogen action with Tam, breast cancer cells also adapt by changing their response to estradiol $\left(\mathrm{E}_{2}\right)$ and by developing an increased sensitivity to its growth-stimulating action (Martin et al. 2003, Berstein et al. 2004, Santen et al. 2004). This so-called hypersensitivity to $E_{2}$ was shown to be associated with increased concentrations of ER $\alpha$ and ER-mediated events (Santen et al. 2001, Chan et al. 2002). The presence of elevated levels of MAPK or Akt activity was also shown to be involved in the development of $\mathrm{E}_{2}$ hypersensitivity (Yue et al. 2002, 2003). Interestingly, long-term exposure of MCF-7 cell xenografts to Tam enhances sensitivity to both $\mathrm{E}_{2}$ and the estrogenic effects of Tam (Berstein et al. 2004), suggesting that these two events are potentially linked.

MVLN is an ER $\alpha$-positive and hormone-responsive human breast carcinoma cell line derived from MCF-7 (Demirpence et al. 1993). Treatment of MVLN cells for 6 months allowed the emergence of $\mathrm{OH}$-Tam-resistant (OTR), but still estrogen-dependent, individual cellular clones that have not been fully characterized (Badia et al. 2000). Large-scale studies of gene expression using cDNA or oligonucleotide arrays have been performed successfully to select molecular targets associated with estrogen regulation (Vendrell et al. 2004) or with antagonist and agonist activity of SERMs (Hodges et al. 2003, Frasor et al. 2004). In this study we aimed to identify variations in gene expression associated with the OH-Tam and $\mathrm{E}_{2}$ pharmacological responses of two MVLN-derived OTR cell lines because such variations might play a critical role in the development or the signature of $\mathrm{OH}$ Tam resistance. Two OTR cell lines, namely CL6.8 and CL6.32, were explored concomitantly, with the purpose of delineating the common and different molecular events acquired by two individual cellular clones issued from the same selection process. By combining mini-array gene selection and extensive real-time quantitative PCR (RTQ-PCR) exploration, we identified specific signaling pathways and genes associated with an agonist activity of OH-Tam and/or a hyperresponse to $E_{2}$ in the two OTR cell lines studied. As modifications of MAPK activity, modification of the phosphorylation status of $\mathrm{ER} \alpha$ and quantitative changes in transcriptional co-regulators could be mechanisms contributing to the emergence of such responses, we explored these mechanisms in the two OTR cell lines. This study provides for the first time an extensive exploration of the multifactorial events associated with the development of $\mathrm{OH}-\mathrm{Tam}$ resistance in a resistant cell model and should enhance our knowledge of the cancer cell-regulatory pathways involved in both the agonist activity of $\mathrm{OH}$-Tam and the hyper-response to $\mathrm{E}_{2}$.

\section{Materials and methods}

\section{Cell culture}

MVLN, CL6.8 and CL6.32 cells were grown during one or two passages as described previously (Demirpence et al. 1993), then purged for 4 days in Dulbecco's 
modified Eagle's medium without Phenol Red and supplemented with $3 \%$ steroid-depleted, dextrancoated, charcoal-treated fetal calf serum (DCC medium). The cells were then treated for 4 days (with one media change) under the pharmacological conditions described below.

\section{Cell-cycle distribution analysis by flow cytometry}

The cells were purged in DCC medium for 4 days and then grown for 4 days in the presence of vehicle, $1 \mathrm{nM}$ $\mathrm{E}_{2}, 200 \mathrm{nM} \mathrm{OH}-\mathrm{Tam}$ or both $1 \mathrm{nM} \mathrm{E}_{2}$ and $200 \mathrm{nM}$ $\mathrm{OH}-\mathrm{Tam}$. The cells were harvested and washed twice with PBS. $10^{6}$ cells were then incubated with $1 \mathrm{ml}$ DNA staining solution $(25 \mu \mathrm{g} / \mathrm{ml}$ propidium iodide, $0.1 \%$ sodium citrate, $0.1 \%$ Triton $\mathrm{X}-100$ ) for $24 \mathrm{~h}$ at $4{ }^{\circ} \mathrm{C}$. Propidium iodide fluorescence of 20000 nuclei was analyzed for each sample by FACScan flow cytometer (Becton Dickinson, Mountain View, CA, USA). The percentage of cells within the $G_{0} / G_{1}, S$ and $G_{2} / M$ phases of the cell cycle were identified by analysis with the Modfit $\mathrm{LT}^{\mathrm{TM}}$ software (Verity Software, Topsham, ME, USA).

\section{Cell-proliferation analysis}

The cells were purged in DCC medium for 4 days and then plated at 12000 cells/well on a 96-well tissueculture plate in DCC medium. 1 day later the cells were treated for 1, 3, 5 or 8 days with vehicle, $1 \mathrm{nM} \mathrm{E}_{2}$ or $200 \mathrm{nM}$ OH-Tam. Proliferating cells were analyzed using the Cell Proliferation ELISA, 5-bromodeoxyuridine (BrdU; colorimetric) Kit (Roche, Meylan, France). Briefly, the cells were labeled for $24 \mathrm{~h}$ with BrdU and the labeled nuclei were identified using a specific anti-BrdU antibody according to the manufacturer's recommendations.

\section{Detection of apoptotis by annexin $\mathrm{V}$ staining}

The cells were purged in DCC medium for 4 days and then grown for 4 days in either the absence of any treatment or the presence of $600 \mathrm{nM}$ of OH-Tam. Apoptotic cells were detected using the AnnexinV-FLUOS Staining Kit (Roche). Briefly, cells were harvested, washed twice with PBS and $10^{6}$ cells subsequently labeled with fluorescein isothiocyanate (FITC)-annexin V according to the manufacturer's recommendations. FITC fluorescence of 20000 cells was then analyzed by flow cytometry. The percentage of apoptotic cells was determined by analysis with CellQuest $^{\mathrm{TM}}$ software (Becton Dickinson).

\section{Neutral Red cytotoxicity assay}

The cells were plated at 12000 cells/well on a 96-well tissue culture plate in DMEM medium and treated for 4 days with different concentrations of OH-Tam $\left(10^{-9}\right.$ to $\left.10^{-4} \mathrm{M}\right)$. After 4 days of treatment the medium was removed and the cells were incubated for $3 \mathrm{~h}$ with Neutral Red at $33 \mathrm{mg} / \mathrm{l}$. Cells were then washed twice with PBS and lysed in the presence of $1 \%$ acetic acid/ $50 \%$ ethanol. After $15 \mathrm{~min}$ of gentle shaking the absorbance was measured at $540 \mathrm{nM}$. The uptake of Neutral Red is proportional to the number of viable cells.

\section{Hybridization of complex probe and cDNA-array data analysis}

Variations in gene-expression levels were analyzed by large-scale measurement with home-made nylon cDNA mini-arrays $(7.5 \times 11.5 \mathrm{~cm} ; 1019$ human genes; 12 genes $/ \mathrm{cm}^{2}$ ) produced in our facility (TAGC Laboratory, CIML, University of Aix-Marseille II, Marseille, France) as described previously (Bertucci et al. 1999, Vendrell et al. 2004). Spotted targets were single amplified PCR products amplified from control clones and IMAGE cDNA clones (IMAGE Consortium, Cambridge, UK). The human cDNA clones were selected on the basis of practical criteria (Bertucci et al. 1999), and the genes were chosen because of a proven or putative implication in cancer (oncogenes and tumor suppressors, apoptosis and cell-cycle regulators, transcription factors and transcriptional coregulators, DNA-repair regulators, cytokines, growth factors, adhesion molecules, nuclear receptors, enzymes, etc.) The list is available at http://tagc.univmrs.fr/pub/Cancer/. Total RNA was extracted by $\mathrm{CsCl}$ ultracentrifugation and RNA integrity was checked by denaturing agarose-gel electrophoresis. Hybridization to each array with a ${ }^{33} \mathrm{P}$-labeled probe synthesized by reverse-transcribing $5 \mu \mathrm{g}$ total RNA was performed as described previously (Bertucci et al. 1999). Array data scanning, quantification and normalization were performed as described previously (Vendrell et al. 2004); hybridization signals were scanned with a FUJI BAS 5000 beta imager (Raytest, Asnieres, France), then quantified with the HDG Analyzer software (Genomic Solution, Ann Arbor, MI, USA) by integrating all spot pixel intensities and removing a spot background value determined in the neighboring area; intensity values were adjusted by a normalization step based on the DNA quantification of each spot and the sum of intensities detected in each experiment. Expression values were expressed as the ratio of the 
treated cell line gene value to that obtained with the corresponding untreated cell line (the ratio was called fold change or FC).

\section{RTQ-PCR analysis}

RTQ-PCR measurements were performed as described previously (Girault et al. 2003a, Vendrell et al. 2004) using a LightCycler ${ }^{\circledR}$ (Roche) or an ABI Prism 7700 Sequence Detection System (Perkin-Elmer Applied Biosystems, Foster City, CA, USA) using the corresponding SYBR Green Kit, according to the manufacturer's recommendations. For each set of primers, a standard curve was made with serial dilutions from a control cDNA sample, and high RTQ-PCR efficiency rates were verified for each investigated transcript $(>90 \%)$. We also checked that our RTQPCR measurements were reproducible (the inter-assay variation was less than $5 \%$, as calculated by the s.E.; data not shown). All measurements were normalized to the expression of either the $28 \mathrm{~S}$ ribosomal gene (Vendrell et al. 2004) or the TATA box-binding protein (TBP) gene (Girault et al. 2003a).

\section{Western blotting}

Cells were lysed in the presence of $1 \%$ Triton X-100, $1 \%$ sodium deoxycholate, $0.1 \%$ SDS, $1 \mathrm{mM}$ dithiothreitol, $52 \mathrm{mM} \mathrm{NaF}, 40 \mathrm{mM}$ glycerol 2-phosphate disodium salt hydrate, $0.1 \mathrm{mM}$ sodium orthovanadate and protease inhibitor in $20 \mathrm{mM}$ Tris, $\mathrm{pH} 7.5,150 \mathrm{mM}$ $\mathrm{NaCl}, 10 \mathrm{mM}$ Hepes and $5 \mathrm{mM}$ EDTA. For each sample, $50 \mu \mathrm{g}$ total protein was separated on SDS/ PAGE gels before transferring to a PVDF membrane (Sigma-Aldrich, St Quentin Fallavier, France). Membranes were then incubated with the appropriate primary antibody, and detection was performed as recommended by the manufacturer with horseradish peroxidase-conjugated secondary antibody using the ECL Plus ${ }^{\mathrm{TM}}$ western blotting detection reagents (Amersham Biosciences, Orsay, France). The ER $\alpha$ antibody was from Santa Cruz Biotechnology (Santa Cruz, CA, USA); the bcl2 antibody from Lab Vision Corporation (Fremont, CA, USA); cyclin A2 and tubulin antibodies were from Sigma Chemical Co. (Saint-Louis, MO, USA); the Bak antibody was from Calbiochem (Darmstadt, Germany); the PCNA antibody was from eBioscience (San Diego, SA, USA) and the phospho-p44/42 MAPK, p44/42 MAPK, survivin and phospho-ser118 ER $\alpha$ antibodies were from Cell Signaling (Beverly, MA, USA).

\section{Results}

\section{Relative resistance to $\mathrm{OH}-\mathrm{Tam}$ and functionality of ER-mediated transcription in CL6.8 and CL6.32 cell lines}

OH-Tam dose-response experiments (Neutral Red cytotoxicity assay) were performed to measure the concentration giving rise to a $50 \%$ reduction in cellular viability $\left(\mathrm{IC}_{50}\right.$ values). The $\mathrm{IC}_{50}$ values (means \pm s.D.) from three independent experiments were $1.5 \pm 0.28$, $8.5 \pm 1.3$ and $8.6 \pm 0.93 \mu \mathrm{M}$ in the MVLN, CL6.8 and CL6.32 cell lines, respectively. These data demonstrate that the CL6.8 and CL6.32 cell lines both displayed a 5.7-fold relative resistance to $\mathrm{OH}$-Tam compared with MVLN (Student's $t$-test; $P<0.0001$ ). One of the possible mechanisms that could lead to OH-Tam resistance is altered expression of $E R \alpha$ and $E R \beta$ (Johnston et al. 1995, Speirs et al. 1999). In accordance with previous observations (Badia et al. 2000), we confirmed that ER $\alpha$ protein expression was lower (approximately 6-fold) in CL6.8 and CL6.32 cells than in MVLN cells (data not shown). Investigation of the ER $\beta$ mRNA level by RTQ-PCR demonstrated an expression level that was 1000 -fold lower than that of $E R \alpha$ mRNA and no difference in expression between the three cell lines (data not shown). We also validated the functionality of the ER $\alpha$ and the basal transcription machinery in MVLN, CL6.8 and CL6.32 by verifying that $E_{2}$ treatment elicited an increase in Trefoil factor 1 (TFF1) (pS2) expression in the three cell lines at both the mRNA and the protein levels, and that $\mathrm{OH}-\mathrm{Tam}$ was able to counteract this effect (data not shown).

\section{$E_{2}$ exerts a hyper-response and $\mathrm{OH}-\mathrm{Tam}$ an agonist activity on the proliferation of the OTR CL6.8 and CL6.32 cells}

To investigate the effect of $\mathrm{E}_{2}$ and $\mathrm{OH}$-Tam exposure on cell proliferation of MVLN, CL6.8 and CL6.32 cells we first assessed cell-cycle distribution by flowcytometry analysis. Figure 1 reveals that treatment with $E_{2}$ stimulated a great percentage of cells to enter to $S$ phase in the three cell lines (Fig. 1, compare panel A with $\mathrm{B}, \mathrm{E}$ with $\mathrm{F}$ and $\mathrm{I}$ with $\mathrm{J}$ ). However, the proportion of cells in the $S$ phase under $E_{2}$ treatment was greater in the two OTR cell lines than in the MVLN cells ( 35 vs $26 \%$; Fig. 1 compare panel $\mathrm{F}$ and $\mathrm{J}$ with B). Investigation of the growth kinetics of MVLN, CL6.8 and CL6.32 cells under $\mathrm{E}_{2}$ exposure (Fig. 2A) also highlighted differences between the MVLN and the OTR cells: (i) the $\mathrm{E}_{2}$-stimulated cell growth was significantly detectable on day 5 for the 


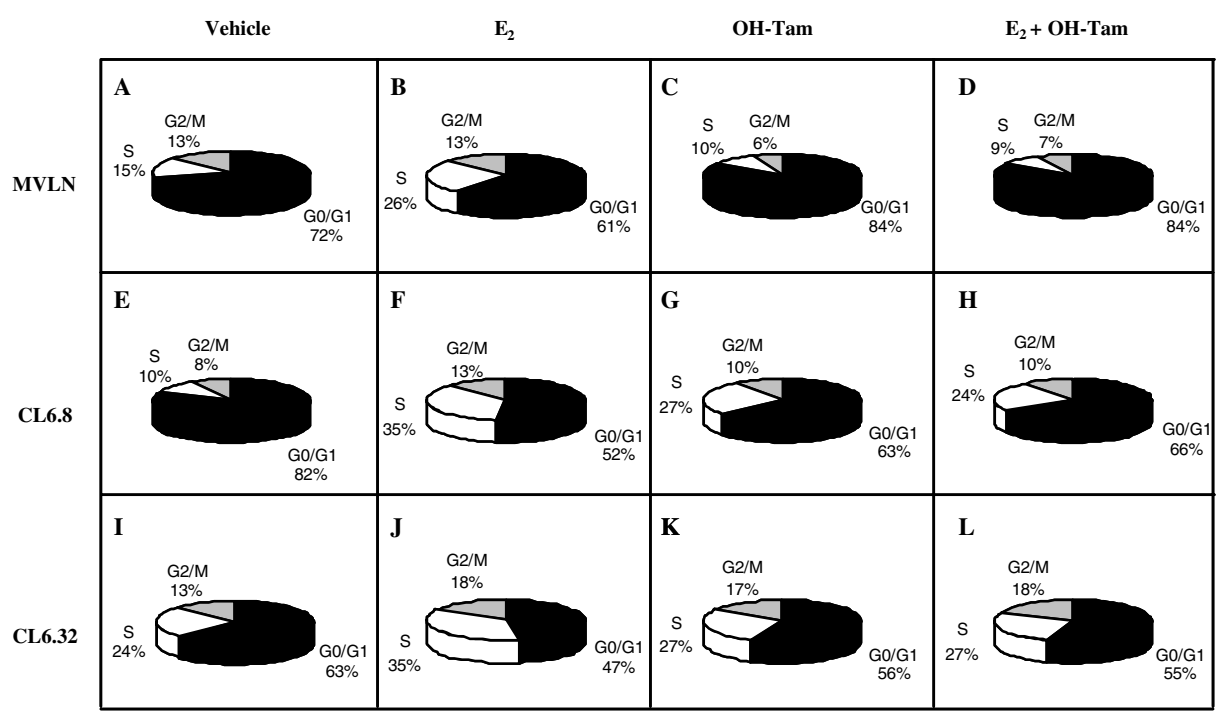

Figure 1 Cell-cycle distribution of MVLN, CL6.8 and CL6.32 cells in response to $\mathrm{E}_{2}$ and OH-Tam. Cells were treated over a period of 4 days with vehicle, $1 \mathrm{nM} \mathrm{E2,} 200 \mathrm{nM} \mathrm{OH}-T a m$ or both $\mathrm{E}_{2}(1 \mathrm{nM})$ and OH-Tam $(200 \mathrm{nM})$ as described in the Materials and methods section. Cells were then stained with propidium iodide, and nuclei were analyzed for DNA content by flow cytometry. Values shown are from one experiment that was reproduced at least three times. The percentage of cells in the $\mathrm{GO} / \mathrm{G} 1, \mathrm{~S}$ and $\mathrm{G} 2 / \mathrm{M}$ phases are indicated on the pie charts.

MVLN cells $(P<0.01)$ but earlier (day 3$)$ for the CL6.8 and CL6.32 cells $(P<0.05)$; (ii) the amplitude of $E_{2}$-stimulation of cell proliferation was significantly greater in the two OTR cell lines than in the MVLN cells (days 3, 5 and 8).

We next investigated the proliferating response of MVLN, CL6.8 and CL6.32 cells under OH-Tam exposure. OH-Tam treatment of MVLN cells was able to totally antagonize the $E_{2}$-stimulatory effect on S-phase entry and to induce growth arrest in $G_{0} / G_{1}$ (Fig. 1C and D). On the contrary, OH-Tam exposure of the CL6.8 and CL6.32 cells was associated with a higher proportion of cells in the $\mathrm{S}$ phase than in MVLN cells (27 versus 10\%, Fig. 1, compare panel G and $\mathrm{K}$ with $\mathrm{C}$ ). Exposure of the two OTR cell lines under both $\mathrm{E}_{2}$ and $\mathrm{OH}$-Tam treatments gave patterns of cell distribution identical to those obtained under $\mathrm{OH}-\mathrm{Tam}$ alone (Fig. 1, compare panels $\mathrm{H}$ and $\mathrm{L}$ with $G$ and $K$ respectively), suggesting the absence of any additive or synergic effect between $\mathrm{E}_{2}$ and $\mathrm{OH}$-Tam in the two OTR cells. The growth kinetics assay illustrated in Fig. 2B confirmed that, in agreement with a previous study (Semlali et al. 2004), OH-Tam was able to stimulate the proliferation of the two OTR cell lines.

Taken together, our findings demonstrate an increase of amplitude of $E_{2}$ stimulation of cell proliferation (hyper-reponse to $\mathrm{E}_{2}$ ) and estrogenic-like effects of OH-Tam (agonist activity) in the OTR CL6.8 and CL6.32 cell lines.

\section{Global assessment of the $\mathrm{E}_{2}$ and $\mathrm{OH}$-Tam responses in the OTR CL6.8 and CL6.32 cell lines by cDNA-array analysis}

With the aim of selecting specific genes or signaling pathways associated with the agonist activity of $\mathrm{OH}-$ Tam and the hyper-response to $E_{2}$, we performed global gene expression profiling using a 1019 human gene mini-array on MVLN and OTR CL6.8 and CL6.32 cells exposed for 4 days to four different pharmacological conditions: no treatment, $\mathrm{E}_{2}$, $\mathrm{OH}-\mathrm{Tam}$ or treatment with both $\mathrm{E}_{2}$ and $\mathrm{OH}-\mathrm{Tam}$. We demonstrated previously that selection of geneexpression variations based on a cut-off value (called fold change or FC) of 1.7 combined with three independent cell-culture replicates gave reliable results that could be validated at both the mRNA and protein levels (Vendrell et al. 2004). We thus identified genes whose expression was $\mathrm{E}_{2}$-regulated $(\mathrm{FC} \geq 1.7)$ in MVLN, CL6.8 and CL6.32 cell lines; 50 upregulated genes and 26 downregulated genes resulted from this selection (results not shown).

We then assessed the agonist activity of OH-Tam on these 76 genes by identifying the proportion of genes responding to the following criteria: $\mathrm{FC} \geq 1.7$ under $\mathrm{OH}$-Tam exposure and $\mathrm{FC} \geq 1.7$ under the pharmacological conditions combining both $\mathrm{E}_{2}$ and $\mathrm{OH}-\mathrm{Tam}$ exposure. We then defined, as proposed by Frasor and colleagues (Frasor et al. 2004), full agonistic activity 
A

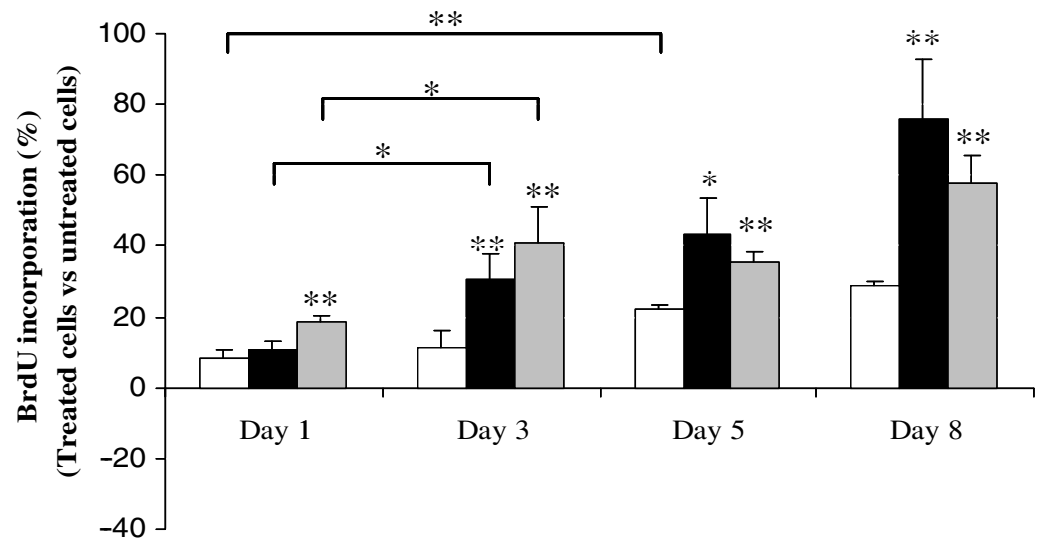

B

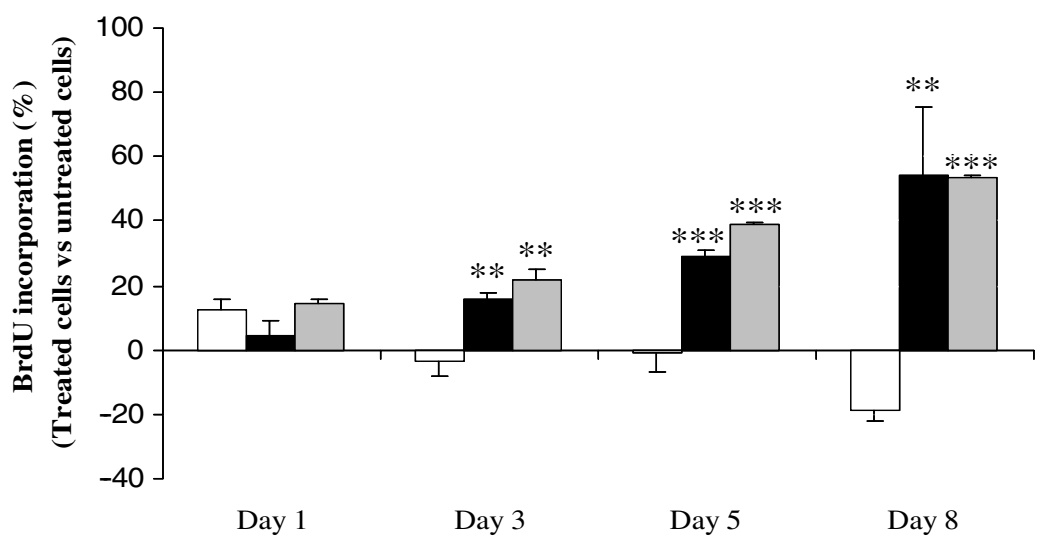

Figure 2 Growth kinetics of MVLN, CL6.8 and CL6.32 cells. MVLN (white bars), CL6.8 (black bars) and CL6.32 (grey bars) cells were grown in DCC medium, then treated for $1,3,5$ or 8 days with vehicle, $1 \mathrm{nM} E_{2}$ (A) or $200 \mathrm{nM} \mathrm{OH}-\mathrm{Tam}(B)$. The proliferative response was assessed by BrdU labeling. Results are expressed as a percentage of cells incorporating BrdU in the presence of treatment compared with untreated cells. Results are means \pm s.D. from three independent experiments. ${ }^{*} P<0.05$, ${ }^{* *} P<0.01,{ }^{* *} P<0.001$ versus the corresponding MVLN treatment according to Student's $t$-test.

(if $\mathrm{OH}$-Tam alone evoked $>70 \%$ of $\mathrm{E}_{2}$ activity and the reversion of $\mathrm{E}_{2}$ activity by $\mathrm{OH}-\mathrm{Tam}$ was $<30 \%$ ) and partial agonist action (if $\mathrm{OH}-\mathrm{Tam}$ alone evoked activity $>35 \%$ but $\leq 70 \%$ of $E_{2}$ activity, and if the effect of $\mathrm{E}_{2}$ could be reversed by OH-Tam by $30-50 \%$ ). Antagonist action of OH-Tam was defined by an FC value of $<1.7$ under OH-Tam treatment and an FC value of $<1.7$ under both $\mathrm{E}_{2}$ and $\mathrm{OH}-\mathrm{Tam}$ treatment. The data presented in Fig. 3 revealed that OH-Tam elicited an antagonist action in the MVLN cells on the majority of the $E_{2}$-regulated genes as well as a subsequent agonistic action (16 and $23 \%$, considering the up- and downregulated genes respectively), in accordance with previous observations (Hodges et al. 2003, Frasor et al. 2004). The OH-Tam response of the two OTR cell lines was strikingly different. Indeed, both CL6.8 and CL6.32 cells demonstrated an increase in the global $\mathrm{OH}-\mathrm{Tam}$ agonistic action on the $\mathrm{E}_{2}$ upregulated genes (38 and 30\%, respectively, comapred with the $16 \%$ detected in MVLN cells), mainly due to an increase in the full agonist activity of the drug. Considering the $E_{2}$ down-regulated genes, a slight increase in the $\mathrm{OH}-\mathrm{Tam}$ full agonist action was noted in the two OTR clones compared with the MVLN cells (19.2 vs $11.5 \%$ ), whereas the global agonistic activity of OH-Tam did not show any difference.

We then assessed variations in the amplitude of the estrogenic response for the $76 \mathrm{E}_{2}$-regulated genes by considering arbitrarily that this latter was increased in CL6.8 and CL6.32 cells when an $\mathrm{E}_{2}$-induced variation of gene expression was superior or equivalent to $200 \%$ of the corresponding variation measured in $\mathrm{E}_{2}$-treated MVLN cells. An increase in the amplitude of the 


\section{$\mathrm{E}_{2}$ up-regulated genes}

MVLN

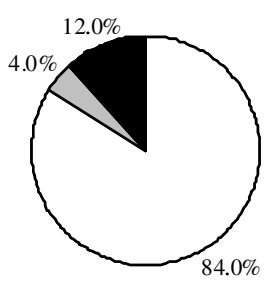

MVLN

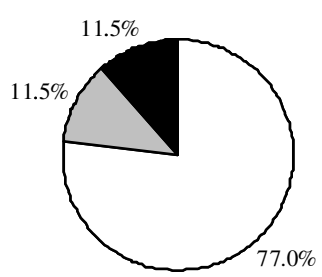

CL6.8

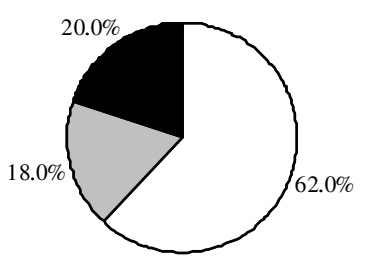

$\mathrm{E}_{2}$ down-regulated genes
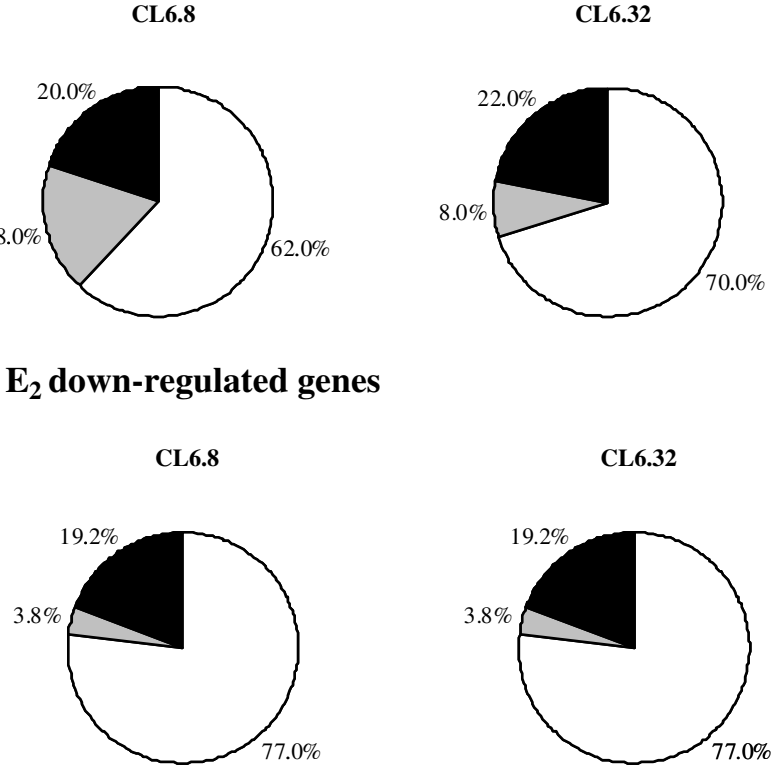

Figure $3 \mathrm{OH}-\mathrm{Tam}$ response of genes up- $(n=50)$ or down-regulated $(n=26)$ by $\mathrm{E}_{2}$. OH-Tam activity was defined as: full agonism (black segments) if the $\mathrm{FC}$ value was $\geq 1.7$ under $\mathrm{OH}-\mathrm{Tam}$ treatment, if $\mathrm{FC} \geq 1.7$ under both $\mathrm{E}_{2}$ and $\mathrm{OH}$-Tam treatment, if $\mathrm{OH}$-Tam alone evoked $>70 \%$ of $\mathrm{E}_{2}$ activity and if reversion of $\mathrm{E}_{2}$ activity by $\mathrm{OH}-\mathrm{Tam}$ was $<30 \%$; partial agonism (grey segments) if $\mathrm{FC} \geq 1.7$ under $\mathrm{OH}$-Tam treatment, if $\mathrm{FC} \geq 1.7$ under both $\mathrm{E}_{2}$ and $\mathrm{OH}$-Tam treatment, if $\mathrm{OH}$-Tam alone evoked activity $>35 \%$ but $\leq 70 \%$ of $\mathrm{E}_{2}$ activity, and if reversion of the $\mathrm{E}_{2}$ effect by $\mathrm{OH}$-Tam was 30-50\%; antagonism (white segments) if $\mathrm{FC}<1.7$ under $\mathrm{OH}-\mathrm{Tam}$ treatment and $\mathrm{FC}<1.7$ under both $\mathrm{E}_{2}$ and $\mathrm{OH}-\mathrm{Tam}$ treatment.

estrogenic response was identified in the OTR cells for a substantial proportion of the genes: $40 \%$ of the upregulated genes and $23 \%$ of the downregulated genes in CL6.8 cells, and 30\% of the upregulated genes and $19 \%$ of the downregulated genes in CL6.32 cells. The amplitude of the estrogenic response detected in these genes ranged from 200 to $862 \%$. Moreover, we also identified several other genes whose expression varied under $\mathrm{E}_{2}$ treatment in the OTR cells but not in the MVLN cells $(2.5 \%$ of the genes investigated in our study).

In conclusion, global assessment by cDNA array of gene-expression variations detected under $\mathrm{E}_{2}$ and $\mathrm{OH}$ Tam treatment suggested an increased agonist activity of OH-Tam and an increased response to $E_{2}$ in both OTR cell lines. A great proportion of the genes associated with these two events were genes coding for proteins involved in cell proliferation, cell-cycle regulation, cell transformation and apoptosis. We thus decided to further explore by RTQ-PCR the signaling pathways identified by the array data. Figure 4 illustrates validation by RTQ-PCR of particular gene-expression variations selected by cDNA-array analysis and demonstrates an excellent consistency between the cDNA-array results and the RTQ-PCR measurements (as we observed previously (Vendrell et al. 2004)).

\section{$E_{2}$ exerts a hyper-response at the level of gene expression in the OTR CL6.8 and CL6.32 cell lines}

Table 1 illustrates compiled RTQ-PCR data measuring the expression variations of 36 selected genes in the MVLN, CL6.8 and CL6.32 cell lines under $\mathrm{E}_{2}, \mathrm{OH}-$ Tam or both $\mathrm{E}_{2}$ and $\mathrm{OH}-\mathrm{Tam}$ treatment. Analysis of the data revealed at the gene-expression level a hyperresponse to $E_{2}$ in the OTR cell lines, defined by (i) the detection of $\mathrm{E}_{2}$-induced gene-expression variations that were not measured in MVLN cells (GADD45A, STK6) Aurora-A, CDKN1A/p21/Cip1, EGR2/KROX20, MBD2, DNMT3B, TRADD, TRAF1, TNFSF10/ $A P O 2 L / T R A I L)$ or (ii) the increase of the amplitude of the $\mathrm{E}_{2}$ response measured in MVLN cells (ranging from 200 to $1370 \%$ of the $\mathrm{E}_{2}$ response detected in MVLN cells). Taken together, 61 and 39\%, respectively, of the gene-expression variations measured in $\mathrm{E}_{2}$-treated CL6.8 and CL6.32 cell lines displayed at the gene-expression level a hyper-reponse to $\mathrm{E}_{2}$, and $86 \%$ of the hyper-response to $\mathrm{E}_{2}$ detected in CL6.32 cells 

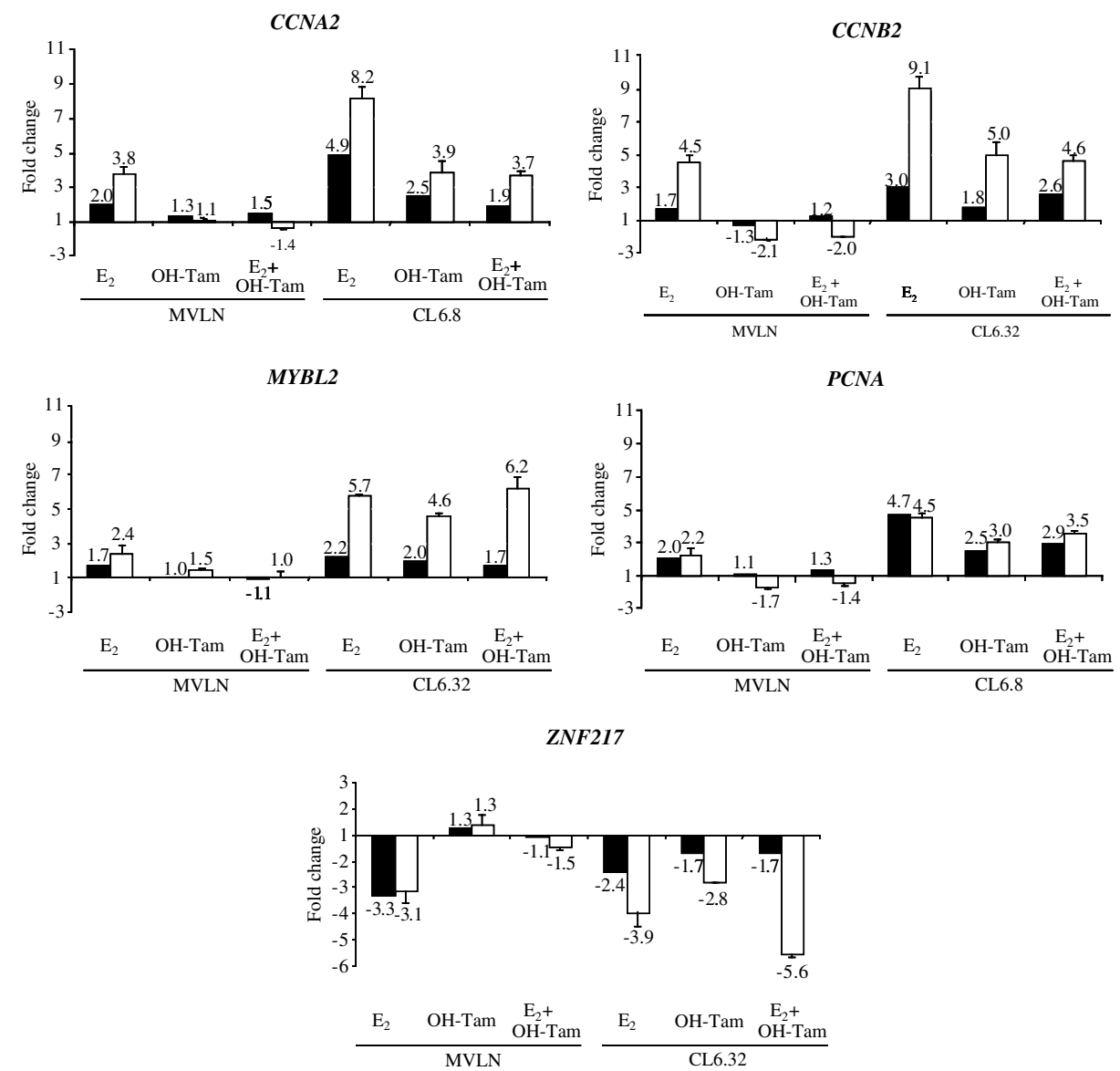

Figure 4 Comparison of the gene-expression variations (FC) measured by cDNA arrays (black bars) and RTQ-PCR (white bars) after 4 days of $\mathrm{E}_{2}, \mathrm{OH}-\mathrm{Tam}$ or both $\mathrm{E}_{2}$ and $\mathrm{OH}-\mathrm{Tam}$ treatment of MVLN, CL6.8 and CL6.32 cells. The RTQ-PCR values indicated are means from at least three independent experiments.

was also present in CL6.8 cells. Gene-expression variations associated with the hyper-reponse to $E_{2}$ affected upregulated genes encoding proteins associated with stimulatory effects on cell proliferation or transformation (e.g. PCNA, STK6/Aurora-A, CCNA2, CCNB2, CCNE2, MYBL2, PTTG1/Securin, $M A D 2 L 1, T E R T)$ or with negative effects on apoptosis (BCL2, BIRC5/Survivin), and downregulated genes encoding proteins known to exert suppressive effects on growth (GADD45A, CDKN1A/p21/Cip1, EGR2/ $K R O X 20, T G F B 2)$ or pro-apoptotic action (EGR2/ KROX20, TGFB2, TRADD, TRAF1, TNFSF10/ $A P O 2 L / T R A I L, B A K)$. Hyper-response to $\mathrm{E}_{2}$ was validated by Western-blot analysis in CL6.8 cells for cyclin A2, PCNA, Bak, survivin and Bcl2 proteins and represented 810, 190, 190, 550 and $220 \%$, respectively, of the $E_{2}$ response detected in MVLN cells (data not shown). The correlation between expression variations detected at the mRNA level and at the protein level validated the relevance of the expression modulations we identified under $\mathrm{E}_{2}$ exposure.

\section{Gene-expression variations associated with OH-Tam activity in MVLN cell line}

We further decided to focus on the OH-Tam effects on the expression of genes presented in Table 1. In the MVLN cell line, antagonistic action of OH-Tam was the main phenomenon, as OH-Tam was able to counteract $89 \%$ of the $\mathrm{E}_{2}$-induced modulations of gene expression. In previous studies, a 'reverse pharmacology' (defined as genes that were specifically regulated by $\mathrm{OH}$-Tam but either unaffected by $\mathrm{E}_{2}$ exposure or inversely regulated by $\mathrm{E}_{2}$ ) has been identified for only a few genes (Montano \& Katzenellenbogen 1997, Hodges et al. 2003, Frasor et al. 2004). Our data newly 


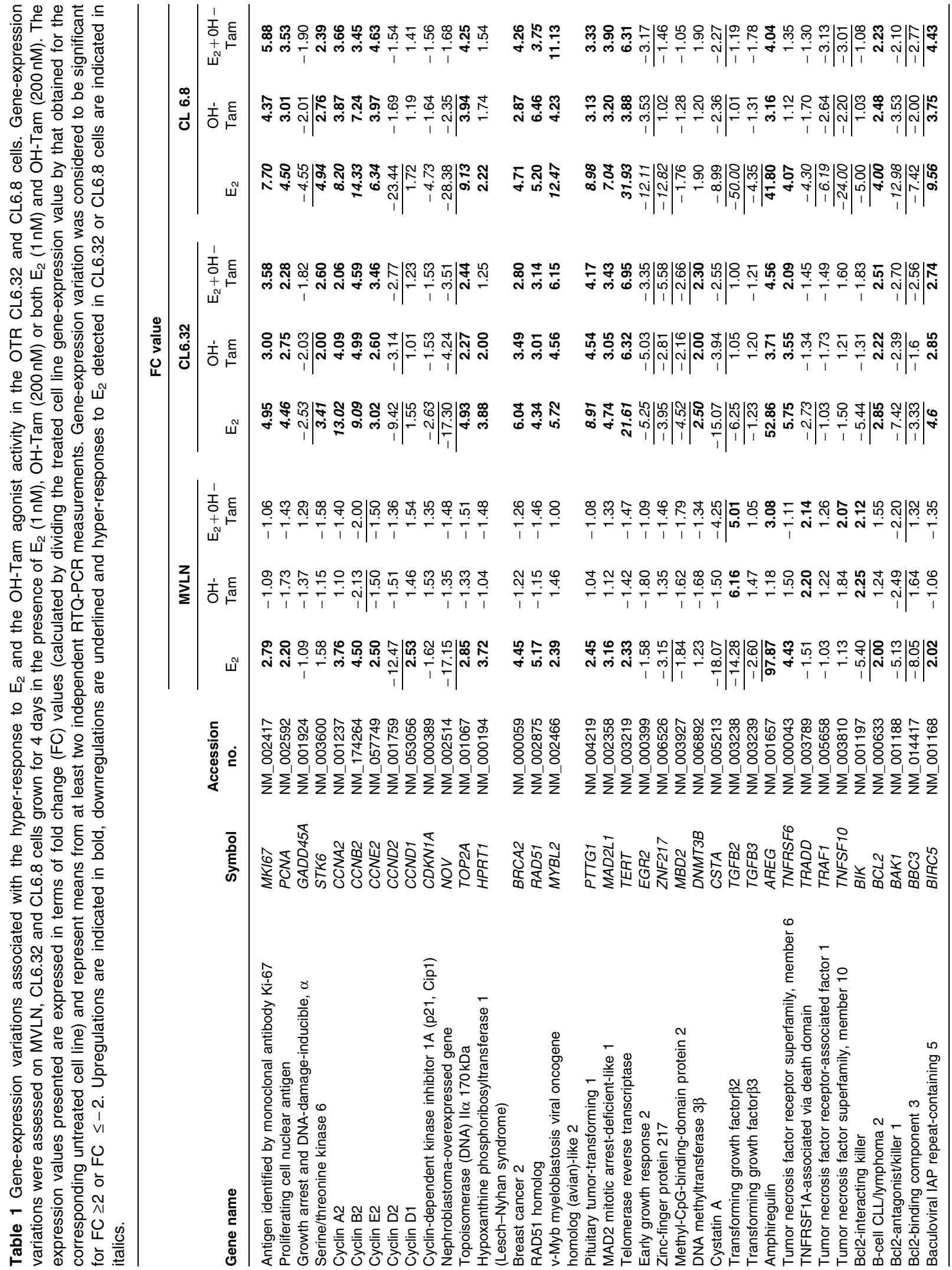




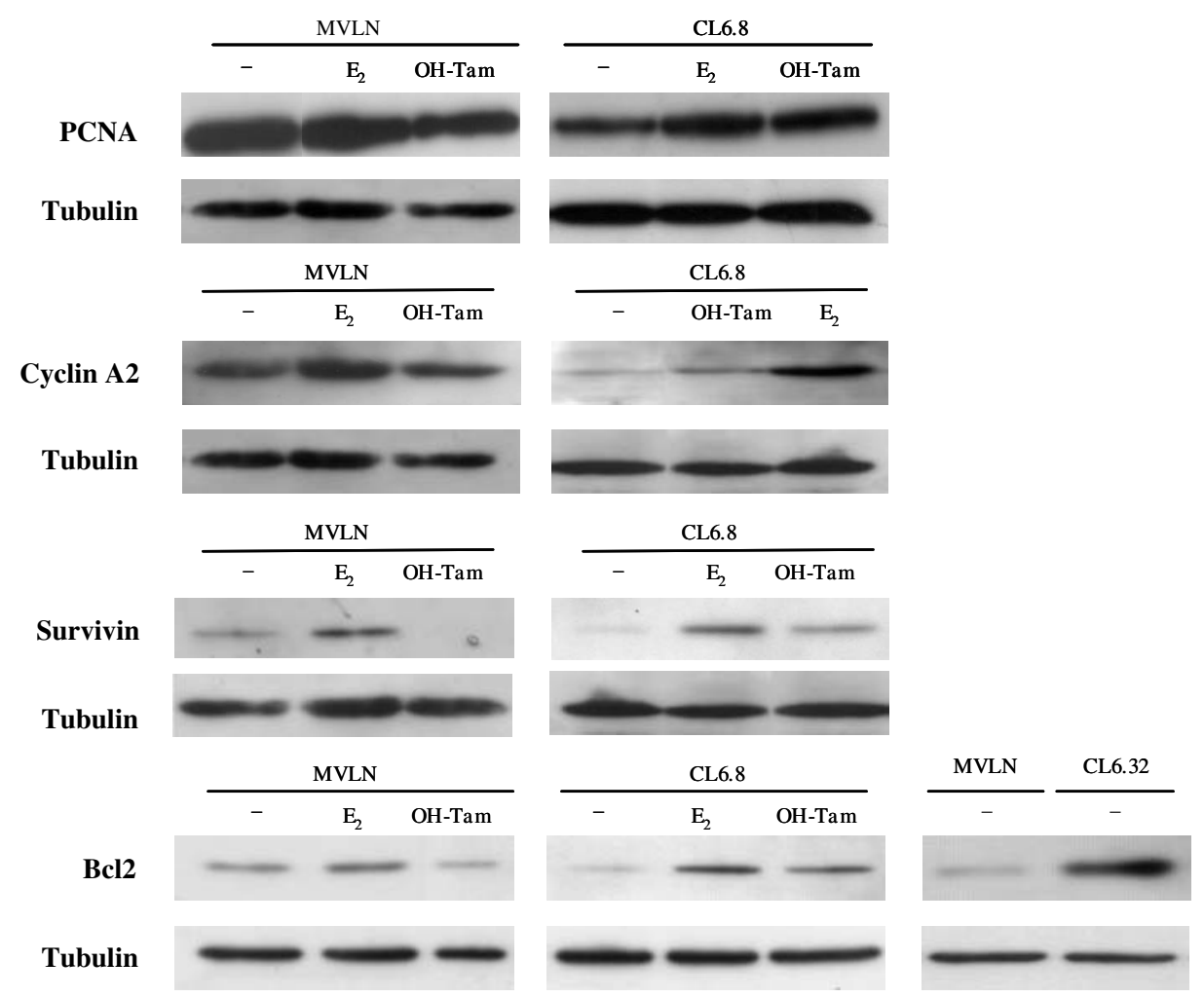

Figure 5 Western-blot analysis of $\mathrm{OH}-\mathrm{Tam}$ agonist activity on the expression of PCNA, cyclin A2, survivin and Bcl2 proteins. Protein expression was analyzed as described in the Materials and methods section using specific antibodies in cells untreated $(-)$ or treated for $4\{\mathrm{Q} 4\}$ days with $1 \mathrm{nM} \mathrm{E} \mathrm{E}_{2}$ or $200 \mathrm{nM} \mathrm{OH}-\mathrm{Tam}$. Tubulin protein level was measured to verify even loading.

identified a reverse pharmacology of OH-Tam for the $C C N B 2, T G F B 2, T R A D D$ and $B I K$ genes in the MVLN cell line.

\section{$\mathrm{OH}-\mathrm{Tam}$ elicited an agonist activity at the gene expression level in the OTR CL6.8 and CL6.32 cell lines}

Contrary to what was observed in the MVLN cell line, $\mathrm{OH}-\mathrm{Tam}$ agonistic activity (i.e. an 'estrogen-like' signature) was the main phenomenon identified in the two OTR cell lines, and represented $83 \%$ of the gene expressions presented in Table 1. The $\mathrm{OH}-\mathrm{Tam}$ signature was very close to that obtained under both $\mathrm{E}_{2}$ and $\mathrm{OH}-\mathrm{Tam}$ exposure, suggesting the absence of any additive or synergic effect between $\mathrm{E}_{2}$ and $\mathrm{OH}-\mathrm{Tam}$ in the two OTR cells. Of much interest was the function of the genes associated with the agonist activity of OH-Tam in the CL6.8 and CL6.32 cells (Table 1). Indeed, agonist activity of OH-Tam was associated with (i) the upregulation of the expression of genes coding for proteins involved in positive stimulation of cell proliferation or in cell-cycle regulation
(PCNA, STK6/Aurora-A, CCNA2, CCNB2, CCNE2, $M A D 2 L 1, A R E G /$ Amphiregulin), in DNA replication and genomic stability (TOP2A, HPRT1, TERT), in DNA repair (BRCA2, RAD51) and in cell transformation (MYBL2, PTTG1/Securin), (ii) the downregulation of the expression of genes encoding proteins involved in negative regulation of cell proliferation (GADD45A, NOV, EGR2/KROX20). The most striking example was that of the CCNB2 gene, encoding a protein which regulates $G_{2} / M$ transition, on which $\mathrm{OH}-\mathrm{Tam}$ exerted a reverse pharmacology in MVLN cells but agonist activity in the CL6.8 and CL6.32 cells. Validation at the protein level of the $\mathrm{OH}$-Tam agonist activity on cyclin A2 and PCNA proteins is illustrated in Fig. 5.

Interestingly, no agonistic action of $\mathrm{OH}-\mathrm{Tam}$ was observed on the expression of CCND1, at the mRNA (Table 1) or protein (data not shown) level, which codes for a protein known to play an essential role in $\mathrm{E}_{2}$-induced cell-cycle progression. Furthermore, RTQ-PCR measurements of the mRNA levels of other genes involved in the regulation of cell proliferation (CCND3, CCNE1, CDKN1B, WEE1) demonstrated 
no variation of expression under any of the pharmacological conditions tested (data not shown). Taken together, these observations suggest that these five genes do not seem to be involved in the development of $\mathrm{OH}$-Tam resistance.

\section{The OTR CL6.8 and CL6.32 cells are not responsive to $\mathrm{OH}-\mathrm{Tam}$-induced apoptosis}

Tam has been reported to have anti-proliferative effects but also to increase cell death (Zhang et al. 1999). We thus decided to explore the impact of OHTam treatment on cell death in the two OTR cell lines. Apoptotic cells were stained with FITC-annexin V and analyzed by flow cytometry in three independent experiments. We confirmed that $\mathrm{OH}$-Tam was able to elicit cell death in MVLN cells (the proportion of apoptotic cells was $14.0 \%$ in OH-Tam-treated cells compared with $8.9 \%$ in untreated cells; $P=0.001$ ). Interestingly, the gene-expression variations presented in Table 1 revealed that OH-Tam exposure of MVLN cells was associated with the upregulation of three pro-apoptotic genes, TGFB2, TRADD and BIK. On the contrary, OH-Tam treatment did not elicit any significant apoptotic response in the CL6.8 and CL6.32 cell lines. Indeed, the proportion of apoptotic cells was $7.7 \%$ in OH-Tam-treated CL6.8 cells compared with $8.0 \%$ in untreated CL6.8 cells, and $4.2 \%$ in OH-Tamtreated CL6.32 cells vs $4.4 \%$ in untreated CL6.32 cells. At the gene-expression level, we observed (Table 1) (i) the absence of OH-Tam upregulation of TGFB2, $T R A D D$ and $B I K$ expression, (ii) OH-Tam agonist activity associated with the downregulation of four pro-apoptotic genes coding for two members of the death receptor signaling (TRAF1, TNFSF10/APO2L/ TRAIL), the transcription factor EGR2/Krox-20 and PUMA (encoded by $B B C 3 / P U M A$, a p 53 target gene) and (iii) $\mathrm{OH}-\mathrm{Tam}$ agonist activity associated with an increased expression of anti-apoptotic genes coding for the Bcl2 protein and the survivin protein (BIRC5/ Survivin gene). Validation of agonist activity of $\mathrm{OH}-\mathrm{Tam}$ on $\mathrm{Bcl} 2$ and survivin protein expression is illustrated in Fig. 5. The proportion of apoptotic cells detected by flow cytometry was significantly lower $(P=0.0003)$ in untreated CL6.32 cells vs $(4.4 \%)$ than in untreated MVLN cells $(8.9 \%)$. Interestingly, we found that $\mathrm{Bcl} 2$ levels were more elevated in untreated CL6.32 cells than in untreated MVLN cells, both at the mRNA (data not shown) and protein (Fig. 5) levels. These findings suggest that $\mathrm{Bcl} 2$ could be one of the major actors in the survival network developed by the OTR cell lines during their acquisition of OH-Tam resistance. Besides the data presented in Table 1, we also measured the expression variation of other genes involved in the regulation of apoptosis ( $F A D D$, CRADD, TNFRSF10A, TNFRSF10B, TNFRSF10C, $B A X, A P A F 1$ and $D A P 3$ genes), and no significant variation was observed under the pharmacological conditions tested (data not shown).

\section{The OTR cell lines display at the basal level increased MAPK activity, elevated status of phosphorylation of ER $\alpha$ Ser-118 and over-expression of genes members of the ErbB-driven pathway}

The importance of the MAPK pathway has been demonstrated in the development of anti-estrogen resistance, in Tam agonist activity and in hypersensitivity to $\mathrm{E}_{2}$ (Kato et al. 1995, Coutts \& Murphy 1998, Kurokawa et al. 2000, Yue et al. 2002). We thus assessed the MAPK activity in MVLN, CL6.8 and CL6.32 cells at the basal level (i.e. in the absence of any treatment; Fig. 6A). MAPK activity (expressed as the ratio of active MAPK to total MAPK) was higher in CL6.8 and CL6.32 cells than in MVLN cells (respectively 216 and $171 \%$ of the MAPK activity detected in MVLN cells). The MAPK pathway is able to target and phosphorylate key regulatory sites on the ER protein, notably within the ligand-independent transactivation AF-1 domain, and Ser-118 is a putative target site for phosphorylation by MAPK (Bunone et al. 1996). The data presented in Fig. 6B demonstrate that elevated MAPK activity in the two OTR cell lines was also accompanied by an increase in the basal phosphorylation of ER on Ser-118 (expressed as the ratio of phospho-ER $\alpha$ to total $E R \alpha$ ).

Previous studies have demonstrated that overexpression and/or activation of growth factor ligands and growth factor receptors could promote endocrine resistance and activate the MAPK pathway (Kurokawa et al. 2000, Nicholson et al. 2001). We therefore decided to explore gene-expression mRNA levels of the four members of the ErbB family (erbb1/EGFR, erbb2/ HER2/neu, erbb3/HER3, erbb4) and specific ErbBspecific ligands (EGF, AREG/Amphiregulin, NRG1, NRG2, NRG3, NRG4, BTC, DTR/HBEGF, EREG, $T G F A$, Epigen). Of great interest was the identification in CL6.8 and CL6.32 cells of the over-expression of $E G F R$ and numerous $E r b B$-specific ligands. Indeed, RTQ-PCR measurements of MVLN, CL6.8 and CL6.32 cells revealed an increase in the basal expression of EGFR (FC, +3.1), AREG/Amphiregulin (+2.8), $B T C(+2.0)$ and DTR/HBEGF $(+2.9)$ genes in CL6.8 cells and an increase of the basal expression of Epigen in both CL6.8 and CL6.32 cells (FC, +12.5 and +25.0 , 
A
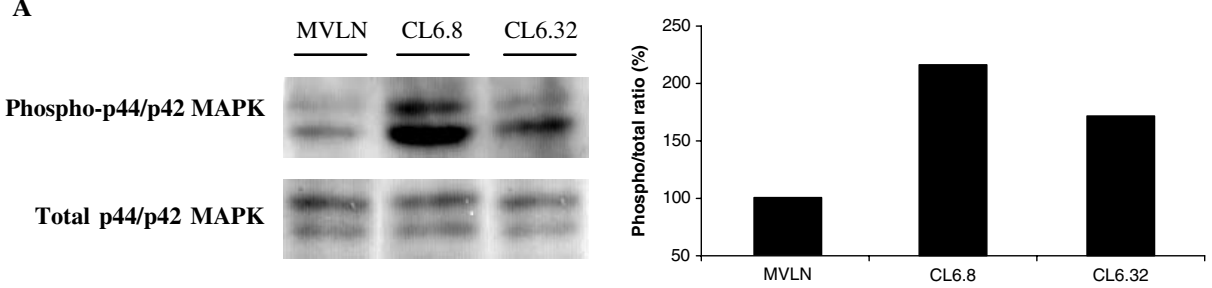

B
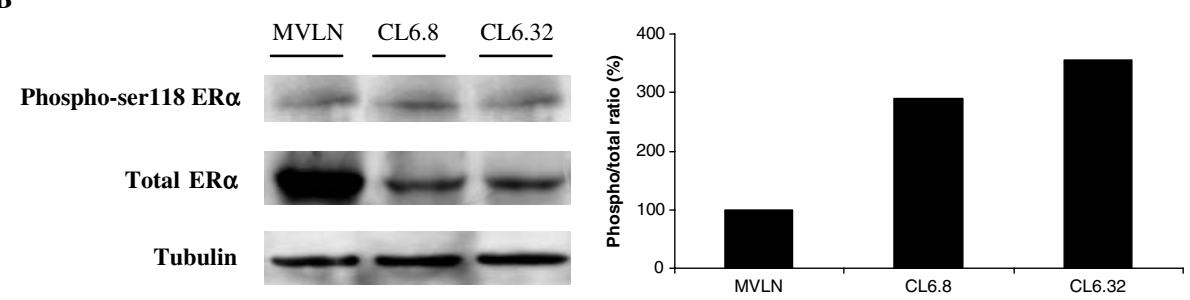

Figure 6 Increase of MAPK activity (A) and the phosphorylation status of the ER $\alpha$ Ser-118 (B) in both OTR cell lines in comparison with MVLN cells. MVLN, CL6.8 and CL6.32 cells were grown for 4 days in DCC medium. Protein levels of phosphorylated MAPK, total MAPK, phosphorylated ER $\alpha$ Ser-118 and total ER $\alpha$ were immuno-detected by Western blot. The levels of activated MAPK and the phosphorylation status of the ER $\alpha$ Ser-118 were determined by densitometry scanning. The values are means from two independent experiments.

respectively). Furthermore, $\mathrm{OH}-\mathrm{Tam}$ was demonstrated to exert an agonist effect leading to the over-expression of the AREG/Amphiregulin gene in the CL6.8 and CL6.32 cell lines (Table 1), reinforcing the basal overexpression of this gene in both cell lines. No geneexpression variation was detected for the erbb2/HER2/ neu, erbb3/HER3, erbb4, NRG2, EREG or TGFA genes, and $N R G 1, N R G 3$ and $N R G 4$ gene expression was undetectable in the three cell lines studied (data not shown).

\section{Expression and regulation of $E R \alpha$ co-regulators in MVLN, CL6.8 and CL6.32 cell lines}

Several studies have suggested that changes in expression levels of cofactors might contribute to enhanced $\mathrm{E}_{2}$-stimulated transcription and $\mathrm{OH}$-Tam agonist activity (Smith et al. 1997, Shang \& Brown 2002). Furthermore, $\mathrm{E}_{2}$ is able to modulate the expression of some co-factors, suggesting that the existence of such regulatory mechanisms could be of physiological importance (Misiti et al. 1998). We thus explored the expression of $23 \mathrm{ER} \alpha$ co-regulators (Girault et al. 2003a) in the MVLN, CL6.8 and CL6.32 cell lines under exposure to $\mathrm{E}_{2}$, OH-Tam or both $\mathrm{E}_{2}$ and $\mathrm{OH}$ Tam. No difference in expression was detected for 14 co-regulators between the MVLN and the OTR cell lines under $\mathrm{E}_{2}$ or OH-Tam treatment $(E P 300$, CARM1, SRCAP, NCOA4, CREBBP, GCN5L2, SMARCA4, SMARCB1, NCOR1/N-CoR, HDACl,
SAP18, HDAC3, MTA1 and MTA2 genes; data not shown). The data presented in Table 2 demonstrate that $E_{2}$ treatment was able to downregulate the expression of several co-factors, either in all three cell lines or in at least one of the OTR cell lines (NCOA2/ TIF2/GRIP1, PCAF, RNF14/ARA54, NCOR2/SMRT, NCOA3/AIB1/ACTR, NCOA1/SRC1, TIF1 and $S A P 30$ genes). Interestingly, the expression of the $S I N 3 B$ gene (coding for a co-repressor protein) was stimulated by OH-Tam in MVLN cells but not in the OTR cells (Table 2). This phenomenon was reinforced by the basal down-regulation of this gene in CL6.8 cells (FC, -2.77; untreated CL6.8 cells versus untreated MVLN cells; data not shown). In addition to $\operatorname{SIN} 3 B$, the co-activator EP300, was the only gene that displayed a variation of expression at the basal level between the OTR cells and the MVLN cells $(\mathrm{FC},+2.31$ and +2.00 , respectively, in CL6.8 and CL6.32 cells). Taken together, these findings highlight dysregulation of expression of several co-regulators between MVLN and the two OTR cell lines and suggest a possible involvement of such events in mediating the responses to $\mathrm{OH}-\mathrm{Tam}$ and $\mathrm{E}_{2}$.

\section{Discussion}

Because Tam-resistant breast tumors often display inappropriate responses such as altered gene expression and growth factor signaling, it is of clinical importance to delineate the molecular changes associated with the 


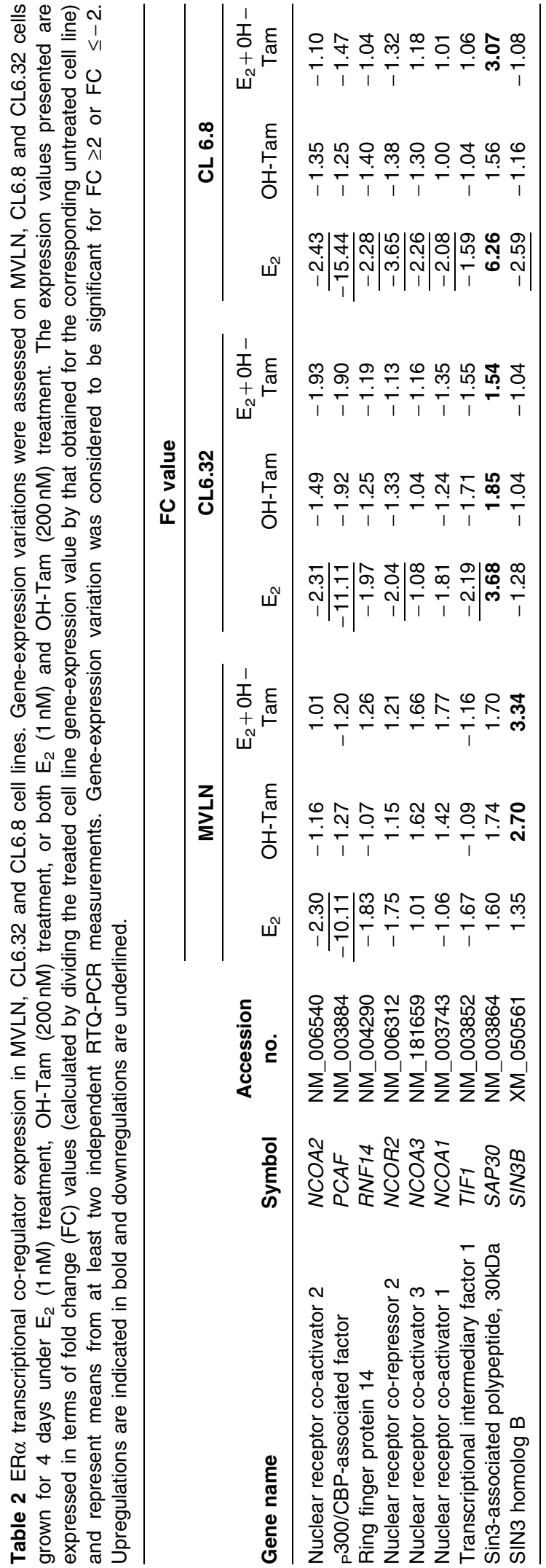

$\mathrm{E}_{2}$ and $\mathrm{OH}-\mathrm{Tam}$ responses in OTR models. Our work provides, for the first time, an extensive study of selective gene-expression patterns associated with both the $\mathrm{E}_{2}$ and $\mathrm{OH}-\mathrm{Tam}$ responses in the OTR CL6.8 and CL6.32 cell lines. These gene-expression variations might play a critical role in the development or the signature of $\mathrm{OH}$-Tam resistance, and these genes could be new candidates as potential diagnostic/prognostic tools for OTR breast cancers. We decided that one of the criteria to select such candidates should be to consider genes whose expression variation was persistent, and which could thus reflect the physiological state of OTR breast tumors. For this reason, the pharmacologic treatment lasted 4 days.

Deprivation or blockade of estrogen action with Tam enhances the level of sensitivity to the stimulating action of $E_{2}$ on cell growth, and this event is associated with increased concentrations of ER $\alpha$ and ER-mediated events (Santen et al. 2001, Chan et al. 2002). Non-genomic actions of $\mathrm{E}_{2}$ (Santen et al. 2004) but also ER-driven transcription events (Martin et al. 2003) have been identified as possible mechanisms. Our study provides evidence of a hyper-response to the growth-stimulatory action of $\mathrm{E}_{2}$ in the OTR CL6.8 and CL6.32 cells. This event was associated with a lower expression level of ER $\alpha$ in CL6.8 and CL6.32 than in MVLN cells, demonstrating for the first time that a high level of ER $\alpha$ is not an absolute necessity for driving a hyper-response to $E_{2}$. We also observed that the hyper-response to $E_{2}$ in the OTR cell lines was associated at the gene-expression level with either the appearance of gene-expression variations that were not detected in MVLN cells or by the increase of the amplitude of the $E_{2}$ response measured in MVLN cells. The detection of a concomitant $\mathrm{OH}-\mathrm{Tam}$ activity (antagonist or agonist effects) on the expression of the concerned genes suggests that these are later regulated by $E_{2}$ through ER-dependent mechanisms or pathways. Our work, however, did not permit us to distinguish between a direct or an indirect action of $\mathrm{E}_{2}$, and future work will be necessary to decipher the exact molecular mechanism mediating the hyperresponse to $\mathrm{E}_{2}$ (e.g. by assessing estrogen responsiveness of promoter/reporter fusion constructs).

Investigation of the OH-Tam response in the OTR CL6.8 and CL6.32 cells demonstrated that this drug stimulates cell proliferation. This event was associated at the gene-expression level with both the loss of the antagonist activity of the drug and the appearance of a so-called estrogen-like signature. The genes identified in such regulations have been reported to encode proteins involved in the regulation of cell proliferation, DNA replication, genomic stability, DNA repair and 
cell transformation and to be associated with the pathogenesis of or the clinical response to breast cancer. For example, PTTG1/Securin expression was recently identified as a prognostic marker of breast tumor aggressiveness (Solbach et al. 2004); high mRNA levels of CCNE2 in breast tumors suggest that the encoded protein contributes to carcinogenesis (Payton et al. 2002); DNMT3B over-expression was associated with poor prognosis in breast tumor (Girault et al. 2003b); NOV encodes for a negative regulator of cell proliferation and its downregulation may be involved in malignant processes (Scholz et al. 1996); high TGFB2 mRNA expression levels in $\mathrm{OH}-$ Tam-treated breast tumors were described as predictive of the clinical response (Brandt et al. 2003); loss of cyclin D2 expression could be associated with the evolution of breast cancer (Evron et al. 2001) and EGR2/Krox-20 functions as a tumor suppressor and has growth-suppressive effects (Unoki \& Nakamura 2001). Taken together, these findings suggest that the genes identified in our study might play a crucial role in OH-Tam-mediated physiological effects and in the development of $\mathrm{OH}-\mathrm{Tam}$ resistance.

Besides its ability to promote $\mathrm{G}_{0} / \mathrm{G}_{1}$ cell-cycle arrest, Tam induces apoptosis in MCF-7 cells in a dose- and time-dependent manner (Zhang et al. 1999). Optimal concentrations demonstrated in studies in vitro usually occur at the micromolar level $\left(10^{-5}\right.$ and $\left.10^{-6} \mathrm{M}\right)$, but lower concentrations of Tam $\left(10^{-7}\right.$ and $\left.10^{-8} \mathrm{M}\right)$ can also trigger a slight but detectable induction of apoptosis (Zhang et al. 1999). In our study, we confirmed that OH-Tam was able to induce apoptosis in MVLN cells in a dose-dependent manner (data not shown). At $200 \mathrm{nM} \mathrm{OH}-\mathrm{Tam}$, the concentration at which the proapoptotic activity of the drug was not found to be maximal, we identified the upregulation of three proapoptotic genes (TGFB2, TRADD and $B I K$ ) that might be early-regulated genes involved in the OH-Tammediated induction of apoptosis (at higher concentrations of OH-Tam, however, other molecular mechanisms probably contribute to the activation of the cell-death process). Supporting this idea, the BIK gene was demonstrated recently to mediate fulvestrantinduced breast cancer cell apoptosis (Hur et al. 2004). Our study also demonstrated that the OTR CL6.8 and CL6.32 cells were refractory to the induction of apoptosis by OH-Tam. Again, this event could be correlated with specific expression patterns of genes coding for proteins involved in the regulation of apoptosis (EGR2/KROX20,TGFB2, TRADD, TRAF1, TNFSF10/APO2L/TRAIL, BIK, BCL2, BBC3/PUMA and BIRC5/Survivin), suggesting the importance of such regulation in the resistance to $\mathrm{OH}$-Tam-induced apoptosis developed by the CL6.8 and CL6.32 cell lines.

We next investigated two possible mechanisms that could contribute to the development of OH-Tam agonist activity and the hyper-response to $E_{2}$ in the OTR cells: (i) the level of MAPK activity and the phosphorylation status of ER $\alpha$ on Ser-118 and (ii) quantitative changes in the expression of transcriptional co-activators and co-repressors.

The activation of EGFR/HER2 and/or MAPK pathways have been demonstrated to contribute to phosphorylation of the AF-1 domain of ER $\alpha$, leading to ligand-independent ER transcription (Kato et al. 1995), Tam agonist activity (Kato et al. 1995) and hypersensitivity to $\mathrm{E}_{2}$ (Yue et al. 2002, Martin et al. 2003, Berstein et al. 2004). Additional studies suggest that in the context of hypersensitivity to $\mathrm{E}_{2}$ (Jeng et al. 2000) or OH-Tam agonistic action (Shou et al. 2004) ER-mediated functions are involved in the elevation of HER2/EGFR and/or MAPK activity, suggesting a complex crosstalk between HER2/EGFR, MAPK, Tam resistance and hypersensitivity to $\mathrm{E}_{2}$. In the present study, we found an increase in MAPK activity, an elevated phosphorylation status of ER $\alpha$ at Ser-118 and over-expression of several genes coding for EGFR and numerous ErbB-specific ligands in the OTR CL6.8 and CL6.32 cells. These observations suggest the possible involvement of such events in the development of the agonist activity of OH-Tam and the hyper-response to $E_{2}$. It can be suggested that the autocrine release of ErbB-specific ligands proteins could promote the activation of the corresponding Erbb receptors and downstream activation of the MAPK pathway. Interestingly, when compared with CL6.32 cells, CL6.8 cells displayed a greater MAPK activity, a more-pronounced over-expression of gene members of the ErbB-driven pathway and a greater $\mathrm{E}_{2}$ hyperresponse and $\mathrm{OH}-\mathrm{Tam}$ agonist activity at the geneexpression level. Taken together, these observations suggest that MAPK activation, hyper-response to $E_{2}$, agonist activity of $\mathrm{OH}-\mathrm{Tam}$ and possible autocrine control might be linked. The precise mechanisms for this interplay are, however, currently unknown, and future work will be necessary to decipher this possible complex crosstalk.

Several studies have suggested that changes in expression levels of cofactors might contribute to enhanced $\mathrm{E}_{2}$-stimulated transcription or $\mathrm{OH}$-Tam agonist activity (Smith et al. 1997, Shang \& Brown 2002). Our study allowed the identification of several differences in $E R \alpha$ transcriptional co-regulator expression between MVLN and OTR cells, suggesting the involvement of such events in the development of $\mathrm{OH}$-Tam resistance 


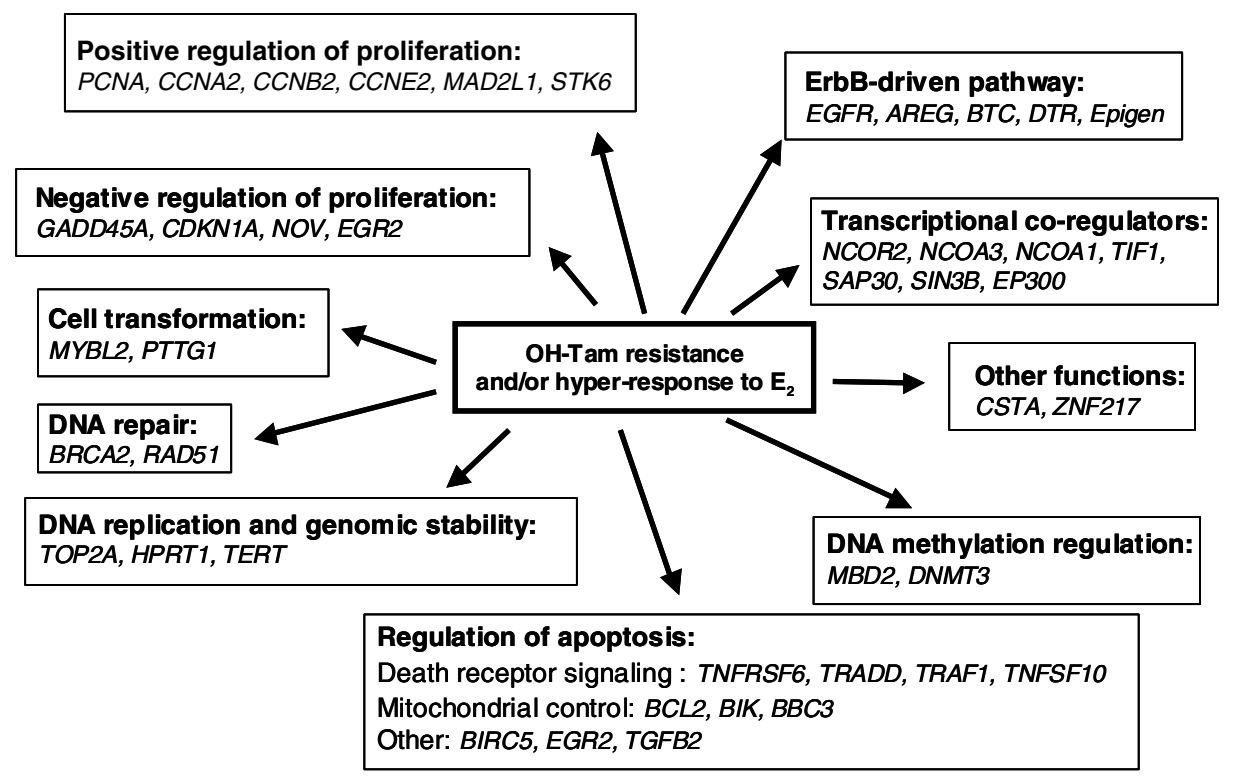

Figure 7 Summary of the gene-expression dysregulation associated with $\mathrm{OH}$-Tam resistance and/or hyper-response to $\mathrm{E}_{2}$ in OTR CL6.8 and CL6.32 cells.

and/or the hyper-response to $\mathrm{E}_{2}$ in OTR cells. The most striking piece of data was observed with the $S I N 3 B$ gene (coding for a transcriptional co-repressor), whose expression was induced under OH-Tam treatment in MVLN cells but not in the OTR cells. Interestingly, this phenomenon was also reinforced in CL6.8 cells by downregulation of the expression of this gene at the basal level. In cells where Tam acts mainly as an antagonist, Tam-bound ER $\alpha$ has been shown to recruit co-repressors (such as SMRT and NcoR) but not co-activators to target promoters (Shang et al. 2000). Thus, it can be suggested that the level of SIN3B expression contributes to dysregulation of the balance between co-activators and co-repressors in the OTR cells and is involved in the development of $\mathrm{OH}-\mathrm{Tam}$ resistance.

In conclusion, the present study allowed the identification of specific gene-expression variations associated with $\mathrm{OH}-\mathrm{Tam}$ resistance and hyper-response to $E_{2}$ in two OTR cells. This is summarized in Fig. 7. Interestingly, 86 and $90 \%$ of the gene-expression variations associated with the hyper-response to $E_{2}$ detected in CL6.8 and CL6.32 cells, respectively, were also associated with $\mathrm{OH}$-Tam agonist activity, suggesting that these two events could be mechanistically linked. Supporting data demonstrated that long-term exposure of MCF-7 cells xenografts to Tam enhances sensitivity, both to $E_{2}$ and the estrogenic effects of Tam (Berstein et al. 2004). The elevated MAPK activity, the phosphorylation status of ER $\alpha$ on Ser-118 and/or the dysregulation in the balance of transcriptional co-regulators we identified in the OTR CL6.8 and CL6.32 cells could be part of the mechanisms contributing to the modified response of these cells to ER ligands. However, other mechanisms such as phosphorylation of ER $\alpha$ at Ser-305 (Michalides et al. 2004), activation of the phosphoinositide 3-kinase/ Akt pathway or phosphorylation of ER $\alpha$ at Ser-167 (Campbell et al. 2001, Martin et al. 2003, Yue et al. 2003) could also be involved and remain to be investigated.

This work also underscores the complexity of $\mathrm{OH}$ Tam resistance, especially the fact that the two OTR cell clones studied displayed molecular changes affecting a great number of genes with various cellular functions, illustrating that the development of $\mathrm{OH}-$ Tam resistance is a multifactorial process involving different molecular events, as observed by others (Brockdorff et al. 2003, Ring \& Dowsett 2004). Interestingly, 56 and $70 \%$ of the gene-expression variations associated, respectively, with the hyper-response to $\mathrm{E}_{2}$ and $\mathrm{OH}$-Tam agonist activity were detected in both the CL6.8 and CL6.32 cells. This suggests that the two individual cell lines displaying a similar degree of relative resistance to $\mathrm{OH}$-Tam and issued from the same selection process could develop different but also common stratagems to escape from OH-Tam action. The delineation of the signaling pathways detected in both OTR cells underlines the importance of such regulations in the acquisition or the signature of 
$\mathrm{OH}-\mathrm{Tam}$ resistance. Our work also provides evidence that $E R \alpha$ over-expression is not a pre-requisite for either induction of hyper-response to $E_{2}$ or development of $\mathrm{OH}-\mathrm{Tam}$ resistance. Interestingly, we observed that the level of ER $\beta$ expression was low and did not display any variation between MVLN cells and the OTR cells. This suggests that ER $\beta$ expression does not seem to be associated with progression from the OH-Tam-sensitive state to the OH-Tam-resistant and $\mathrm{E}_{2}$-hyper-responsive states. In summary, this study provides new information on the molecular events subverting the cellular survival mechanisms associated with the development of OH-Tam resistance and could allow identification of potential molecular targets for diagnosis or therapy.

\section{Acknowledgments}

We thank Dr S L Salhi for editing the manuscript. We are grateful to Dr N Mechti for helpful discussions. We also thank Dr P Martineau and Dr C Theillet for critical comments, Dr C Duperrey for help with the FACS experiments and Miss C Saudray for technical assistance. This work was supported by grants from the Ligue Nationale Contre le Cancer and the Groupement des Entreprises Françaises dans la Lutte Contre le Cancer. J A V was supported by a scholarship from the Ligue Nationale Contre le Cancer (France). The authors declare that there is no conflict of interest that would prejudice the impartiality of this scientific work.

\section{References}

Badia E, Duchesne MJ, Semlali A, Fuentes M, Giamarchi C, Richard-Foy H, Nicolas JC \& Pons M 2000 Long-term hydroxytamoxifen treatment of an MCF-7-derived breast cancer cell line irreversibly inhibits the expression of estrogenic genes through chromatin remodeling. Cancer Research 60 4130-4138.

Berstein LM, Wang JP, Zheng H, Yue W, Conaway M \& Santen RJ 2004 Long-term exposure to tamoxifen induces hypersensitivity to estradiol. Clinical Cancer Research 10 1530-1534.

Bertucci F, Van Hulst S, Bernard K, Loriod B, Granjeaud S, Tagett R, Starkey M, Nguyen C, Jordan B \& Birnbaum D 1999 Expression scanning of an array of growth control genes in human tumor cell lines. Oncogene 18 3905-3912.

Brandt S, Kopp A, Grage B \& Knabbe C 2003 Effects of tamoxifen on transcriptional level of transforming growth factor beta (TGF-beta) isoforms 1 and 2 in tumor tissue during primary treatment of patients with breast cancer. Anticancer Research 23 223-229.
Brockdorff BL, Heiberg I \& Lykkesfeldt AE 2003

Resistance to different antiestrogens is caused by different multi-factorial changes and is associated with reduced expression of IGF receptor Ialpha. Endocrine-Related Cancer 10 579-590.

Bunone G, Briand PA, Miksicek RJ \& Picard D 1996 Activation of the unliganded estrogen receptor by EGF involves the MAP kinase pathway and direct phosphorylation. EMBO Journal 15 2174-2183.

Campbell RA, Bhat-Nakshatri P, Patel NM, Constantinidou D, Ali S \& Nakshatri H 2001 Phosphatidylinositol 3kinase/AKT-mediated activation of estrogen receptor alpha: a new model for anti-estrogen resistance. Journal of Biological Chemistry 276 9817-9824.

Chan CM, Martin LA, Johnston SR, Ali S \& Dowsett M 2002 Molecular changes associated with the acquisition of oestrogen hypersensitivity in MCF-7 breast cancer cells on long-term oestrogen deprivation. Journal of Steroid Biochemistry and Molecular Biology 81 333-341.

Coutts AS \& Murphy LC 1998 Elevated mitogen-activated protein kinase activity in estrogen-nonresponsive human breast cancer cells. Cancer Research 58 4071-4074.

Demirpence E, Duchesne MJ, Badia E, Gagne D \& Pons M 1993 MVLN cells: a bioluminescent MCF-7-derived cell line to study the modulation of estrogenic activity. Journal of Steroid Biochemistry and Molecular Biology 46 355-364.

EBCTC Group 1992 Systemic treatment of early breast cancer by hormonal, cytotoxic, or immune therapy. 133 randomised trials involving 31,000 recurrences and 24,000 deaths among 75,000 women. Lancet 339 71-85.

Evron E, Umbricht CB, Korz D, Raman V, Loeb DM, Niranjan B, Buluwela L, Weitzman SA, Marks J \& Sukumar S 2001 Loss of cyclin D2 expression in the majority of breast cancers is associated with promoter hypermethylation. Cancer Research 61 2782-2787.

Frasor J, Stossi F, Danes JM, Komm B, Lyttle CR \& Katzenellenbogen BS 2004 Selective estrogen receptor modulators: discrimination of agonistic versus antagonistic activities by gene expression profiling in breast cancer cells. Cancer Research 64 1522-1533.

Gee JM, Robertson JF, Ellis IO \& Nicholson RI 2001 Phosphorylation of ERK1/2 mitogen-activated protein kinase is associated with poor response to antihormonal therapy and decreased patient survival in clinical breast cancer. International Journal of Cancer 95 247-254.

Girault I, Lerebours F, Amarir S, Tozlu S, Tubiana-Hulin M, Lidereau R \& Bieche I 2003a Expression analysis of estrogen receptor alpha coregulators in breast carcinoma: evidence that NCOR1 expression is predictive of the response to tamoxifen. Clinical Cancer Research 9 1259-1266.

Girault I, Tozlu S, Lidereau R \& Bieche I 2003b Expression analysis of DNA methyltransferases 1, 3A, and 3B in sporadic breast carcinomas. Clinical Cancer Research 9 4415-4422. 
Gottardis MM \& Jordan VC 1988 Development of tamoxifen-stimulated growth of MCF-7 tumors in athymic mice after long-term antiestrogen administration. Cancer Research 48 5183-5187.

Hodges LC, Cook JD, Lobenhofer EK, Li L, Bennett L, Bushel PR, Aldaz CM, Afshari CA \& Walker CL 2003 Tamoxifen functions as a molecular agonist inducing cell cycle-associated genes in breast cancer cells. Molecular Cancer Research 1 300-311.

Hur J, Chesnes J, Coser KR, Lee RS, Geck P, Isselbacher KJ \& Shioda T 2004 The Bik BH3-only protein is induced in estrogen-starved and antiestrogen-exposed breast cancer cells and provokes apoptosis. PNAS 101 2351-2356.

Jeng MH, Yue W, Eischeid A, Wang JP \& Santen RJ 2000 Role of MAP kinase in the enhanced cell proliferation of long term estrogen deprived human breast cancer cells. Breast Cancer Research Treatment 62 167-175.

Johnston SR 1997 Acquired tamoxifen resistance in human breast cancer-potential mechanisms and clinical implications. Anti-Cancer Drugs 8 911-930.

Johnston SR, Saccani-Jotti G, Smith IE, Salter J, Newby J, Coppen M, Ebbs SR \& Dowsett M 1995 Changes in estrogen receptor, progesterone receptor, and $\mathrm{pS} 2$ expression in tamoxifen-resistant human breast cancer. Cancer Research 55 3331-3338.

Kato S, Endoh H, Masuhiro Y, Kitamoto T, Uchiyama S, Sasaki H, Masushige S, Gotoh Y, Nishida E, Kawashima $\mathrm{H}$, et al. 1995 Activation of the estrogen receptor through phosphorylation by mitogen-activated protein kinase. Science 270 1491-1494.

Kurokawa H, Lenferink AE, Simpson JF, Pisacane PI, Sliwkowski MX, Forbes JT \& Arteaga CL 2000 Inhibition of HER2/neu (erbB-2) and mitogen-activated protein kinases enhances tamoxifen action against HER2overexpressing, tamoxifen-resistant breast cancer cells. Cancer Research 60 5887-5894.

Le Goff P, Montano MM, Schodin DJ \& Katzenellenbogen BS 1994 Phosphorylation of the human estrogen receptor. Identification of hormone-regulated sites and examination of their influence on transcriptional activity. Journal of Biological Chemistry 269 4458-4466.

Liu Y, el-Ashry D, Chen D, Ding IY \& Kern FG 1995 MCF-7 breast cancer cells overexpressing transfected c-erbB-2 have an in vitro growth advantage in estrogendepleted conditions and reduced estrogen-dependence and tamoxifen-sensitivity in vivo. Breast Cancer Research Treatment 34 97-117.

Lupu R, Cardillo M, Cho C, Harris L, Hijazi M, Perez C, Rosenberg K, Yang D \& Tang C 1996 The significance of heregulin in breast cancer tumor progression and drug resistance. Breast Cancer Research Treatment 38 57-66.

Mahfoudi A, Roulet E, Dauvois S, Parker MG \& Wahli W 1995 Specific mutations in the estrogen receptor change the properties of antiestrogens to full agonists. PNAS 92 4206-4210.

Martin LA, Farmer I, Johnston SR, Ali S, Marshall C \& Dowsett M 2003 Enhanced estrogen receptor (ER) alpha,
ERBB2, and MAPK signal transduction pathways operate during the adaptation of MCF-7 cells to long term estrogen deprivation. Journal of Biological Chemistry 278 30458-30468.

Michalides R, Griekspoor A, Balkenende A, Verwoerd D, Janssen L, Jalink K, Floore A, Velds A, van't Veer L \& Neefjes J 2004 Tamoxifen resistance by a conformational arrest of the estrogen receptor alpha after PKA activation in breast cancer. Cancer Cell 5 597-605.

Misiti S, Schomburg L, Yen PM \& Chin WW 1998 Expression and hormonal regulation of coactivator and corepressor genes. Endocrinology 139 2493-2500.

Montano MM \& Katzenellenbogen BS 1997 The quinone reductase gene: a unique estrogen receptor-regulated gene that is activated by antiestrogens. PNAS 94 2581-2586.

Nicholson RI, Hutcheson IR, Harper ME, Knowlden JM, Barrow D, McClelland RA, Jones HE, Wakeling AE \& Gee JM 2001 Modulation of epidermal growth factor receptor in endocrine-resistant, oestrogen receptorpositive breast cancer. Endocrine-Related Cancer $\mathbf{8}$ 175-182.

Osborne CK 1993 Mechanisms for tamoxifen resistance in breast cancer: possible role of tamoxifen metabolism. Journal of Steroid Biochemistry and Molecular Biology 47 83-89.

Osborne CK, Bardou V, Hopp TA, Chamness GC, Hilsenbeck SG, Fuqua SA, Wong J, Allred DC, Clark GM \& Schiff R 2003 Role of the estrogen receptor coactivator AIB1 (SRC-3) and HER-2/neu in tamoxifen resistance in breast cancer. Journal of the National Cancer Institute 95 353-361.

Payton M, Scully S, Chung G \& Coats S 2002 Deregulation of cyclin E2 expression and associated kinase activity in primary breast tumors. Oncogene 21 8529-8534.

Ring A \& Dowsett M Mechanisms of tamoxifen resistance. Endocrine-Related Cancer 11 648-658.

Santen R, Jeng MH, Wang JP, Song R, Masamura S, McPherson R, Santner S, Yue W \& Shim WS 2001 Adaptive hypersensitivity to estradiol: potential mechanism for secondary hormonal responses in breast cancer patients. Journal of Steroid Biochemistry and Molecular Biology 79 115-125.

Santen RJ, Song RX, Zhang Z, Yue W \& Kumar R 2004 Adaptive hypersensitivity to estrogen: mechanism for sequential responses to hormonal therapy in breast cancer. Clinical Cancer Research 10 337S-345S.

Scholz G, Martinerie C, Perbal B \& Hanafusa H 1996 Transcriptional down regulation of the nov proto-oncogene in fibroblasts transformed by p60v-src. Molecular and Cellular Biology 16 481-486.

Semlali A, Oliva J, Badia E, Pons M \& Duchesne MJ 2004 Immediate early gene X-1 (IEX-1), a hydroxytamoxifen regulated gene with increased stimulation in MCF-7 derived resistant breast cancer cells. Journal of Steroid Biochemistry and Molecular Biology 88 247-259.

Shang Y \& Brown M 2002 Molecular determinants for the tissue specificity of SERMs. Science 295 2465-2468. 
Shang Y, Hu X, DiRenzo J, Lazar MA \& Brown M 2000 Cofactor dynamics and sufficiency in estrogen receptorregulated transcription. Cell 103 843-852.

Shou J, Massarweh S, Osborne CK, Wakeling AE, Ali S, Weiss H \& Schiff R 2004 Mechanisms of tamoxifen resistance: increased estrogen receptor-HER2/neu cross-talk in ER/HER2-positive breast cancer. Journal of the National Cancer Institute 96 926-935.

Smith CL, Nawaz Z \& O'Malley BW 1997 Coactivator and corepressor regulation of the agonist/antagonist activity of the mixed antiestrogen, 4-hydroxytamoxifen. Molecular Endocrinology 11 657-666.

Solbach C, Roller M, Fellbaum C, Nicoletti M \& Kaufmann M 2004 PTTG mRNA expression in primary breast cancer: a prognostic marker for lymph node invasion and tumor recurrence. Breast 13 80-81.

Speirs V, Malone C, Walton DS, Kerin MJ \& Atkin SL 1999 Increased expression of estrogen receptor beta mRNA in tamoxifen-resistant breast cancer patients. Cancer Research 59 5421-5424.

Unoki M \& Nakamura Y 2001 Growth-suppressive effects of BPOZ and EGR2, two genes involved in the PTEN signaling pathway. Oncogene 20 4457-4465.
Vendrell JA, Magnino F, Danis E, Duchesne MJ, Pinloche S, Pons M, Birnbaum D, Nguyen C, Theillet C \& Cohen PA 2004 Estrogen regulation in human breast cancer cells of new downstream gene targets involved in estrogen metabolism, cell proliferation and cell transformation. Journal of Molecular Endocrinology 32 397-414.

Yue W, Wang JP, Conaway M, Masamura S, Li Y \& Santen RJ 2002 Activation of the MAPK pathway enhances sensitivity of MCF-7 breast cancer cells to the mitogenic effect of estradiol. Endocrinology 143 3221-3229.

Yue W, Wang JP, Conaway MR, Li Y \& Santen RJ 2003 Adaptive hypersensitivity following long-term estrogen deprivation: involvement of multiple signal pathways. Journal of Steroid Biochemistry and Molecular Biology 86 265-274.

Zhang GJ, Kimijima I, Onda M, Kanno M, Sato H, Watanabe T, Tsuchiya A, Abe R \& Takenoshita S 1999 Tamoxifen-induced apoptosis in breast cancer cells relates to down-regulation of bcl-2, but not bax and bcl- $\mathrm{X}_{\mathrm{L}}$, without alteration of p53 protein levels. Clinical Cancer Research 5 2971-2977. 